\title{
$\mathrm{Al}-\mathrm{Mg}-\mathrm{Si}$ 系合金の粒界割れに及ぼす粒界近傍組織の影響
}

\author{
石澤 真悟* ·倉本 繁**·伊藤 吾朗**
}

Journal of The Japan Institute of Light Metals, Vol. 68, No. 12 (2018), 667-672

(C) 2018 The Japan Institute of Light Metals

\section{Influence of microstructure adjacent to grain boundary on intergranular cracking in $\mathrm{Al}-\mathrm{Mg}-\mathrm{Si}$ alloys}

\author{
Shingo ISHIZAWA*, Shigeru KURAMOTO** and Goroh ITOH**
}

The Al-Mg-Si alloys with excess Si without copper addition have recently been found to suffer from intergranular cracking. In the present study, we have investigated the effects of microstructure adjacent to grain boundaries on the intergranular cracking. It was confirmed that the alloy with excess $\mathrm{Si}$ without $\mathrm{Cu}$ addition had lower elongation to failure caused by higher fraction of intergranular fracture surface consisting of many dimples than balanced alloy and alloy with excess $\mathrm{Si}$ and $\mathrm{Cu}$. Fractographic observations on the pair of fractured test pieces revealed that a grain boundary precipitate was present at the bottom of a dimple in either pieces. In the alloy with excess $\mathrm{Si}$ without $\mathrm{Cu}$, difference in the number of grain boundary precipitates was found within the pair of the pieces, while equal number of precipitates were found in the pair in the other two alloys. Both the size of the precipitates and the amount of precipitation were larger in the alloy with excess $\mathrm{Si}$ without $\mathrm{Cu}$ than the other two alloys. The larger amount of precipitation meant the larger width of PFZ in the alloy. Thus, the larger fraction of intergranular fracture was closely correlated with the larger size of grain boundary precipitates and wider PFZ.

(Received July 5, 2018 Accepted September 25, 2018)

Keywords: Al-Mg-Si alloy; grain boundary; precipitate; cracking; precipitate free zone

\section{1. 緒言}

近年，燃料電池自動車（FCV: Fuel Cell Vehicle）の普及開 始と国際競争力強化の観点から，FCVに関して国内の規制適 正化や，国際基準調和の必要性が高まり，FCV関連の研究 開発等の事業が開始されている ${ }^{1)}$ 。現在の国内基準ではFCV

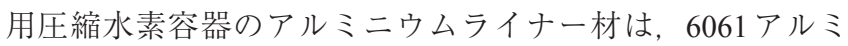
ニウム合金のみが使用可能となっている2)。しかし，6061合 金よりも高強度な 6066, 6069 合金等の材料が使用可能にな れば補強材である CFRPを削減することができ低コスト化に つながる ${ }^{1)}$ 。最近の関係研究により, 水素容器の内面は腐食 環境とならず，またアルミニウムは水素ガスにより脆化しな いので，水素中の不純物水分による長期負荷割れを考慮すれ ばよいこと ${ }^{1)}$ が示された。その試験法として湿潤ガス中で の一種の応力腐食割れ (HG-SCC) 試験が提案されている。

実用 $\mathrm{Al}-\mathrm{Mg}-\mathrm{Si}$ 系合金には合金・不純物元素ごとに様々な 組成範囲が規定されており，ある合金が使用可能と結論する ためには，その組成範囲の中で最も耐 HG-SCC 性に劣る組成 について試験をして合格となることを確認する必要がある。 Fig. 1 に比較的高強度の実用 $\mathrm{Al}-\mathrm{Mg}-\mathrm{Si}$ 系合金の $\mathrm{Mg}, \mathrm{Si}$ の組 成範囲と本研究で用いる試験材の組成を示す ${ }^{3)}$ 。この合金系 の時効析出現象は, しばしば $\mathrm{Mg}$ と $\mathrm{Si}$ の原子比が $2: 1$ の擬 2
元系で論じられるので, Fig. 1 には参考のため, その原子比 が2になる組成（バランス組成）を破線で表記した。荷重漸 増試験での HG-SCC 亀裂進展開始直後の破面観察結果によれ ば，過剩 $\mathrm{Si}$ 合金で粒界割れ破面になり，過剩 $\mathrm{Si}$ 合金への $\mathrm{Cu}$ の添加は粒界割れを抑制するとされている4)。また，90日間

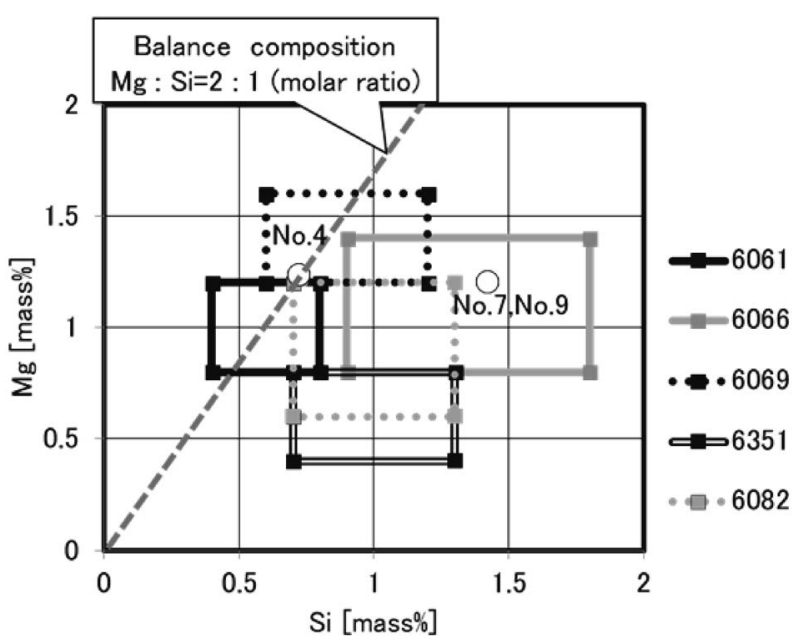

Fig. $1 \mathrm{Mg}$ and $\mathrm{Si}$ compositions of the specimens and of several 6000 series commercial alloys.

*茨城大学大学院理工学研究科 大学院生（₹316-8511 茨城県日立市中成沢町 4-12-1） Graduate School of Science and Engineering, Ibaraki University (4-12-1 Nakanarusawa-cho, Hitachi-shi, Ibaraki 316-8511) E-mail: 16nd201g@vc.ibaraki.ac.jp

**茨城大学工学部（日立市） College of Engineering, Ibaraki University (Hitachi-shi, Ibaraki) 
の HG-SCC 試験における亀裂進展量の合格基準から, No.7 は不合格, No. 4, No. 9は合格と判断された ${ }^{4)}$ 。

$\mathrm{Al}-\mathrm{Mg}-\mathrm{Si}$ 系合金において, 強度を左右する粒内の析出組織 については，これまでに多くの研究がなされ，基礎的にかな り解明が進んでいる ${ }^{5)}$ 。一方, 最高強度を示す時効段階にお ける粒界析出組織については，バランス組成合金では $\beta-\mathrm{Mg}_{2} \mathrm{Si}$ 相が，過剩 $\mathrm{Si}$ 合金では $\beta$ 相のほかに $\mathrm{Si}$ 相が析出するとの報 告がある ${ }^{6)}$ が， $\mathrm{Si}$ 相に関してはそうでないという報告も多 $\left(^{7), 8)}\right.$ 。粒界析出組織や粒界に沿って生じる無析出帯 (PFZ) は, 粒界割れの起こりやすさに関係し ${ }^{9)}$, 耐疲労特性 ${ }^{10) \sim 12)}$, 耐応力腐食割れ (SCC) 性 ${ }^{13)}$ 16) , 勒性・延性 ${ }^{9), 15), 17) ~ な と ゙ の ~}$ 信頼性に大きく影響を及ぼすことが報告されているにもかか わらず，粒界析出組織は粒内より粗大で，サイズ的には捕ら えやすいが，粒界が視野内にない場合があることと，方位関 係の解析が粒内より複雑なことのために機械的特性との関係 で系統的に調べた例はほとんどない。前述のように本系合金 の HG-SCC 特性は過剰 $\mathrm{Si}$ 組成にすることや Cu添加により変化 する。引張特性についても同様である ${ }^{18)}$ 。本研究では粒界析 出組織の観点からの特性向上の原理を調査する基礎的段階と して，主要元素のうち $\mathrm{Mg}$ 量が一定で, $\mathrm{Si}, \mathrm{Cu}$ 量の異なる $\mathrm{Al}$ $\mathrm{Mg}-\mathrm{Si}$ 系合金を用いて実験室大気環境で引張試験を行い，お もに走査型電子顕微鏡（SEM）を用いた破面観察により，粒 界破壊に及ぼす粒界近傍の析出組織の影響を検討した。

\section{2. 実験方法}

\section{1 試料}

供試材料の組成を Table 1 に示す。No. 4 はバランス合金,

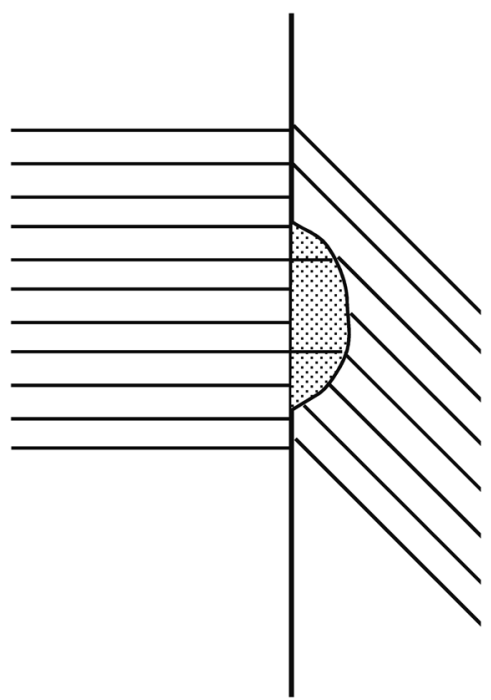

Fig. 2 Example of the orientation relationship between a grain boundary precipitate and two adjacent matrix grains. The precipitate is semi-coherent with the left-side grain and incoherent with the right-side grain.
No. 7 と No. 9 は過剰 $\mathrm{Si}$ 合金である。No. 9 は, No. 7 と Mg, Si 量が同じであるが，耐 HG-SCC特性改善に有効であると報告 されている ${ }^{4)} \mathrm{Cu}$ が添加されている。これらの合金の $7 \mathrm{~mm}$ 厚 の $\mathrm{T} 6$ 材を $430^{\circ} \mathrm{C}$ で $1 \mathrm{~h}$ 焼なましし, 冷間圧延により $1 \mathrm{~mm}$ 厚 とした。この板材を長手方向が圧延方向と平行になるよう に, 平行部寸法 : 幅 $5 \mathrm{~mm} \times$ 長さ $6 \mathrm{~mm}$ の引張試験片を機械加 工により切り出した。その後 T6 調質 $\left(\right.$ No. 4 は $570^{\circ} \mathrm{C}$, No. 7 は $555^{\circ} \mathrm{C}, \mathrm{No} .9$ は $545^{\circ} \mathrm{C}$ でそれぞれ $1 \mathrm{~h}$ 溶体化処理・水冷後, $175^{\circ} \mathrm{C}$ でNo. 4 は $32 \mathrm{~h}$, No. 7 , No. 9 は $14 \mathrm{~h}$ の工時効処理) を施した。溶体化温度は, 示差走査熱分析により溶融開始温 度を求め, その温度より約 $15^{\circ} \mathrm{C}$ 低い温度を溶体化温度と決 め, 一方人工時効条件は, 時効温度を $175^{\circ} \mathrm{C}$ して, 等温時 効を行い $0.2 \%$ 耐力が最大となる時間を $\mathrm{T} 6$ 処理条件とした。

試験片の前処理として, 両面を\#2000まで湿式研磨し， さらにアルカリ洗浄 $(10 \% \mathrm{NaOH}$ 水溶液 $)$ ・デスマット処 理 $\left(10 \% \mathrm{HNO}_{3}\right.$ 水溶液 $)$ を行った。

\section{2 引張試験および破面観察}

引張試験は, 実験室大気中温度 $25^{\circ} \mathrm{C}$, ひずみ速度 1.39 $\times 10^{-3} \mathrm{~s}^{-1}$ で行った。破断後, 破面観察を実施することにより， 機械的特性と破面様相および粒界析出物との関係を調査し た。また，過去の多くの研究により金属材料の粒界はランダ ム粒界がほとんどである ${ }^{19)}$ ので，粒界析出物はFig. 2 に示 すように一方の母相結晶粒と方位関係をもち，他方の母相と は非整合になる場合が一般的と考えられる ${ }^{20)}$ 。そこで破断 前に同一の粒界面でも, 破面に残る粒界析出物の状況が, 破 断後の試験片ごとに異なる可能性があると考えた。そこで破 断した試験片破面の両面を対応させ粒界上析出物の分布や寸 法を比較・検討した。試験片ごとのSEM観察を行った領域 の面積は合計で約 $560 \mu \mathrm{m}^{2}$ である。

\section{3. 実験結果および考察}

Fig. 3 に引張試験で得られた各試料の応力ーひずみ線図を 示す。引張強さや $0.2 \%$ 耐力は, バランス組成のNo. 4 より, 過剩 $\mathrm{Si}$ 組成のNo. 7 が高く，またNo. 7 にCuを添加したNo.

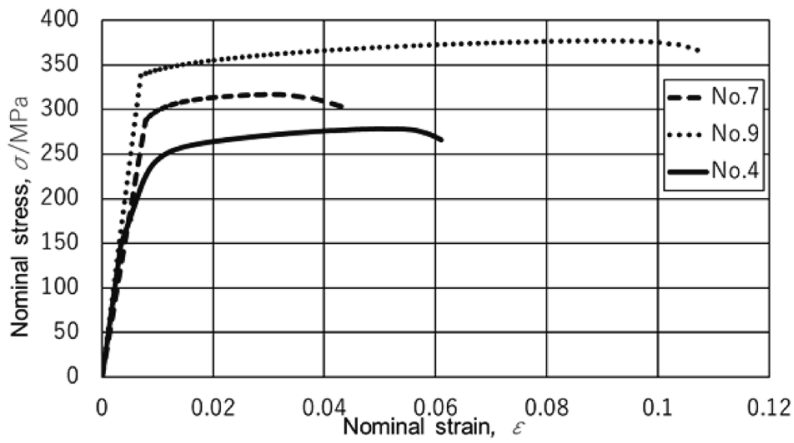

Fig. 3 Stress-strain curves of the three specimens tensiletested at ambient temperature at a strain rate of $1.39 \times 10^{-3} \mathrm{~s}^{-1}$.

Table 1 Composition of the specimens in mass $\%$.

\begin{tabular}{c|c|c|c|c|c|c|c|c}
\hline \hline Specimens & $\mathrm{Si}$ & $\mathrm{Fe}$ & $\mathrm{Cu}$ & $\mathrm{Mn}$ & $\mathrm{Mg}$ & $\mathrm{Cr}$ & $\mathrm{Al}$ \\
\hline No. 4 & 0.70 & 0.10 & $<0.01$ & $<0.01$ & 1.21 & $<0.01$ & $\mathrm{Bal}$ \\
No. 7 & 1.43 & 0.10 & $<0.01$ & $<0.01$ & 1.20 & $<0.01$ & Bal. \\
No. 9 & 1.43 & 0.10 & 0.98 & $<0.01$ & 1.18 & $<0.01$ & $\mathrm{Bal}$. \\
\hline
\end{tabular}



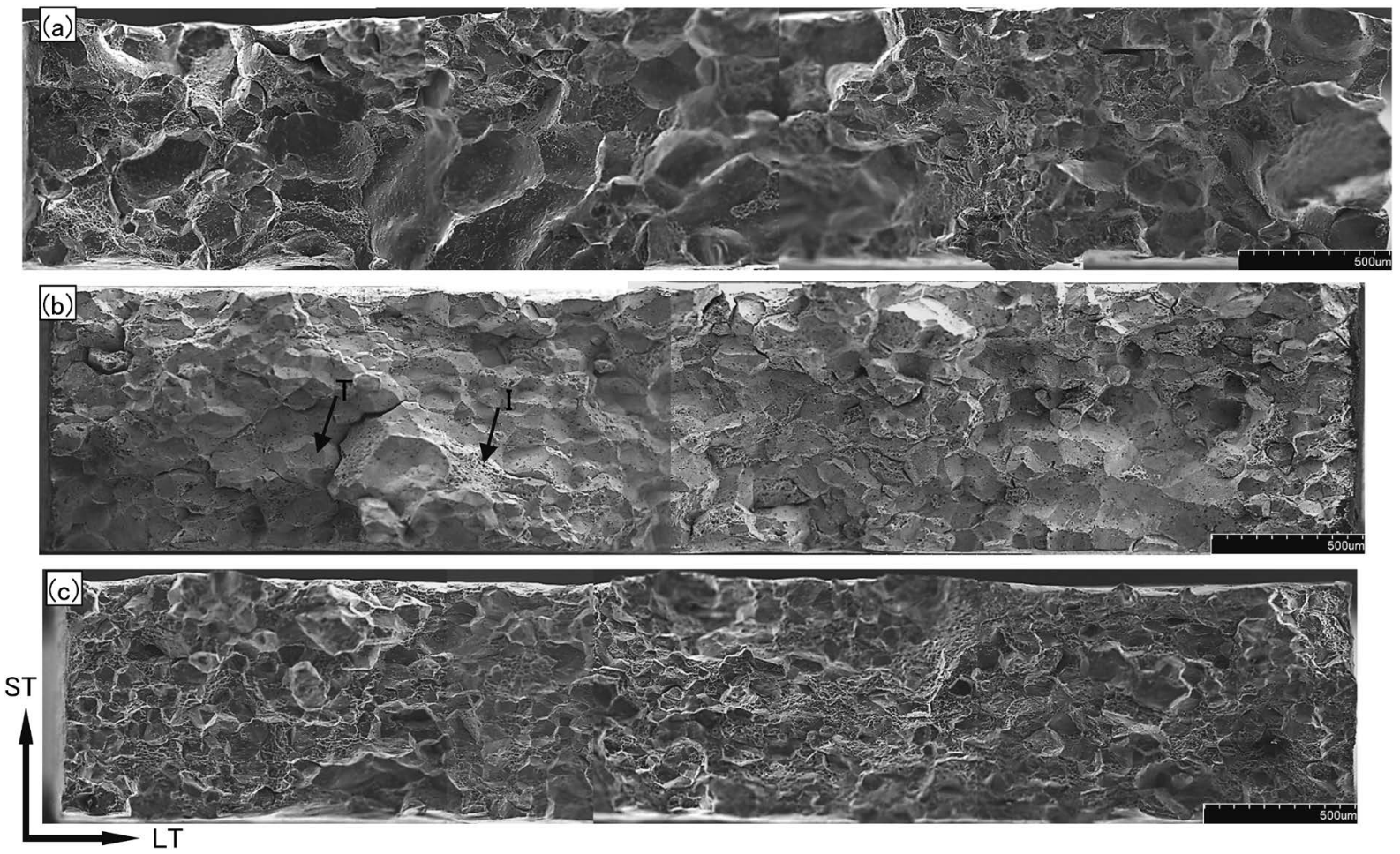

Fig. 4 Fracture surfaces of the three specimens at a low magnification. (a) No. 4, (b) No. 7, and (c) No. 9. Examples of intergranular and transgranular fracture surfaces are indicated as ' $\mathrm{I}$ ' and ' $\mathrm{T}$ ', respectively, in (b).

9がさらに高い值を示している。 $\mathrm{Al}-\mathrm{Mg}-\mathrm{Si}$ 合金で, 同じ $\mathrm{Mg}$ 量 $\left(\mathrm{Mg}_{2} \mathrm{Si}\right.$ 量) ならば, $\mathrm{Si}$ 過剰合金のほうが，また $\mathrm{Cu}$ を添 加したほうが高強度 (高硬度) になることはよく知られて おり $\left.\left.{ }^{8)}, 18\right), 21\right)$ ，本研究における各試料ごとの引張強さや $0.2 \%$ 耐力の大小関係もこれに合致している。一方, 破断伸びは, No.7が最も小さく, No. 4, No.9の順に大きくなる。この傾 向も松田らの報告 ${ }^{18)}$ に一致している。

Fig. 4 は各試料の低倍率の破断面の全体像であり, どの試 料も破面全域で粒界割れが見られる。また，結晶粒径に差が 見られるが, この要因として合金組成の違いと, 調質時の 溶体化温度の違いが挙げられる。すなわちNo. 4 は溶体化温 度が $570^{\circ} \mathrm{C}$ と高かったため結晶粒が粗大となり ${ }^{22)}$, No. 9 は $545^{\circ} \mathrm{C}$ と低いことと $\mathrm{Cu}$ 添加材であるため第二相が完全溶体 化できず粒成長が抑制されたと推察できる ${ }^{23)}$ 。次に, 各試 料の破面の各箇所を粒界割れ破面か，粒内ディンプル破面で あるかで仕分け，粒界か粒内かを判別し，それぞれの破面率 を求め, Fig. 5 に棒グラフで示した。粒界破壊の割合は, バ ランス組成であるNo. 4 が最も少なく，過剩 $\mathrm{Si}$ 組成で $\mathrm{Cu}$ 無添 加のNo. 7 が最も多い。No.9はNo. 7 同様に過剩 Si 組成であ るが, 前述の荷重漸増試験での報告 ${ }^{4)}$ に一致して, $\mathrm{Cu}$ を添 加しているため粒界割れが抑制され，No. 7 に比べ粒界割れ 破面率が20\%減少している。

Fig. 4の破面の一部をより高倍率で観察してみたところ, いずれの試料においても，粒界破面のほとんどがFig. 6 に示 されているようにディンプル形成型の粒界破壊であり，ディ ンプルの底に粒界析出物を確認することができた。

Fig. 7 に，破断した1対の試験片の対応部分の破面観察結 果を示す。No.4, No.9では対応する各面ともにほぼ同数の 粒界析出物が分布している。しかしNo.7では例えば白丸で 囲んだ領域では，左側の破面（ディンプル底）に多くの粒界

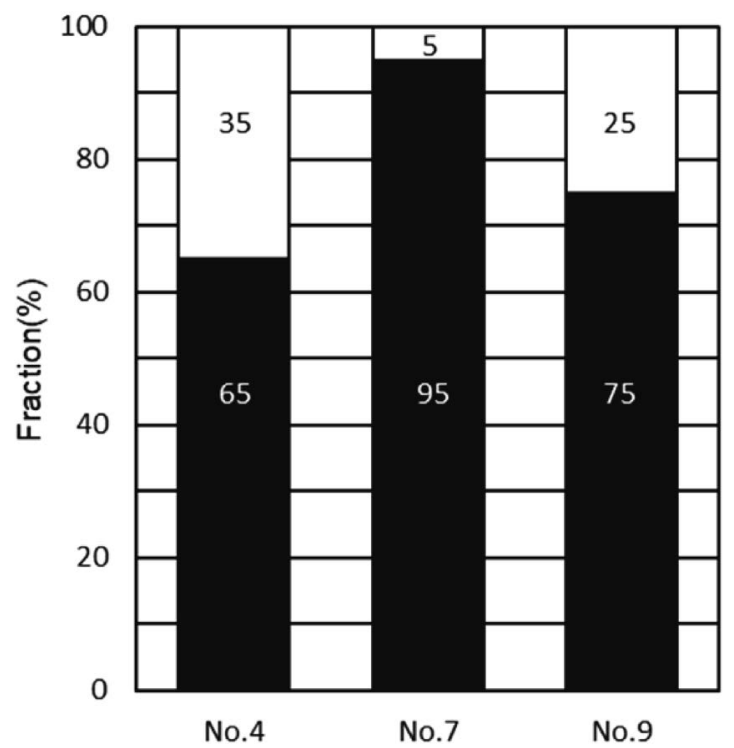

Fig. 5 Fraction of transgranular and intergranular fracture surfaces. Upper (open): transgranular, lower (solid): intergranular.

析出物が見られるのに対して, 右側ではほとんど析出物が見 られない。これは, 既述のように左側の面の母相結晶粒と析 出物が方位関係を持ち, 右側の母相とは非整合であることが 要因と考えられる。しかし他の領域では, No. 4, No. 9 と同 様に偏りが少ない部分も確認できた。

次に粒界析出物の平均寸法 $d$ および観察領域における合計 体積 $V$ （粒界析出量に対応する）を求め, Fig. 8 に示した。す ベてのディンプルの底に析出物があると考えられるが, ディ ンプルの深さや析出物の寸法によっては, 底に析出物が確認 できなかったディンプルもあった。これを考慮し，Vの算出は, 


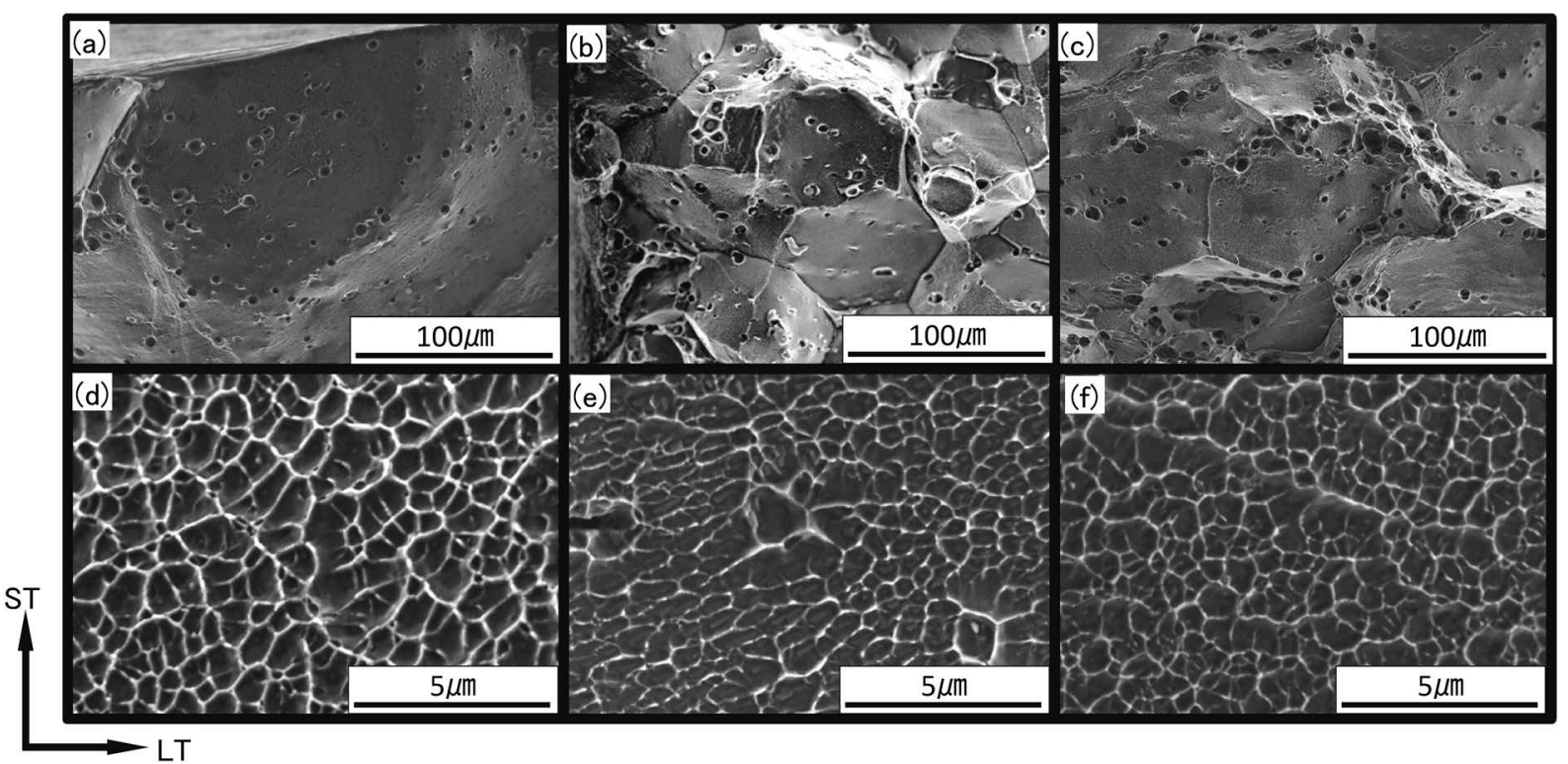

Fig. 6 Fracture surfaces at medium ((a) to (c)) and high ((d) to (f)) magnifications. (a) and (d) No. 4, (b) and (e) No. 7, (c) and (f) No. 9.

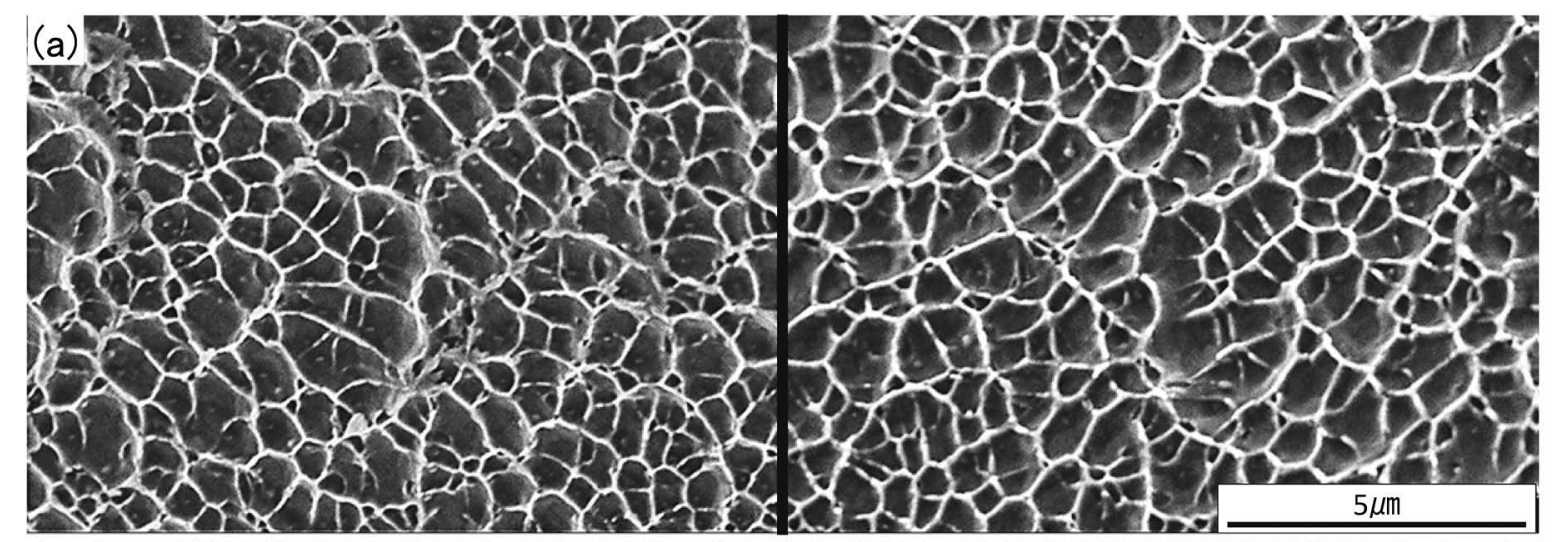

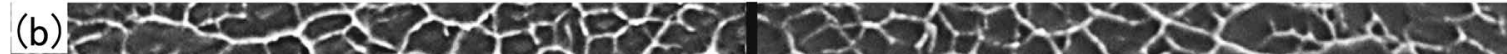
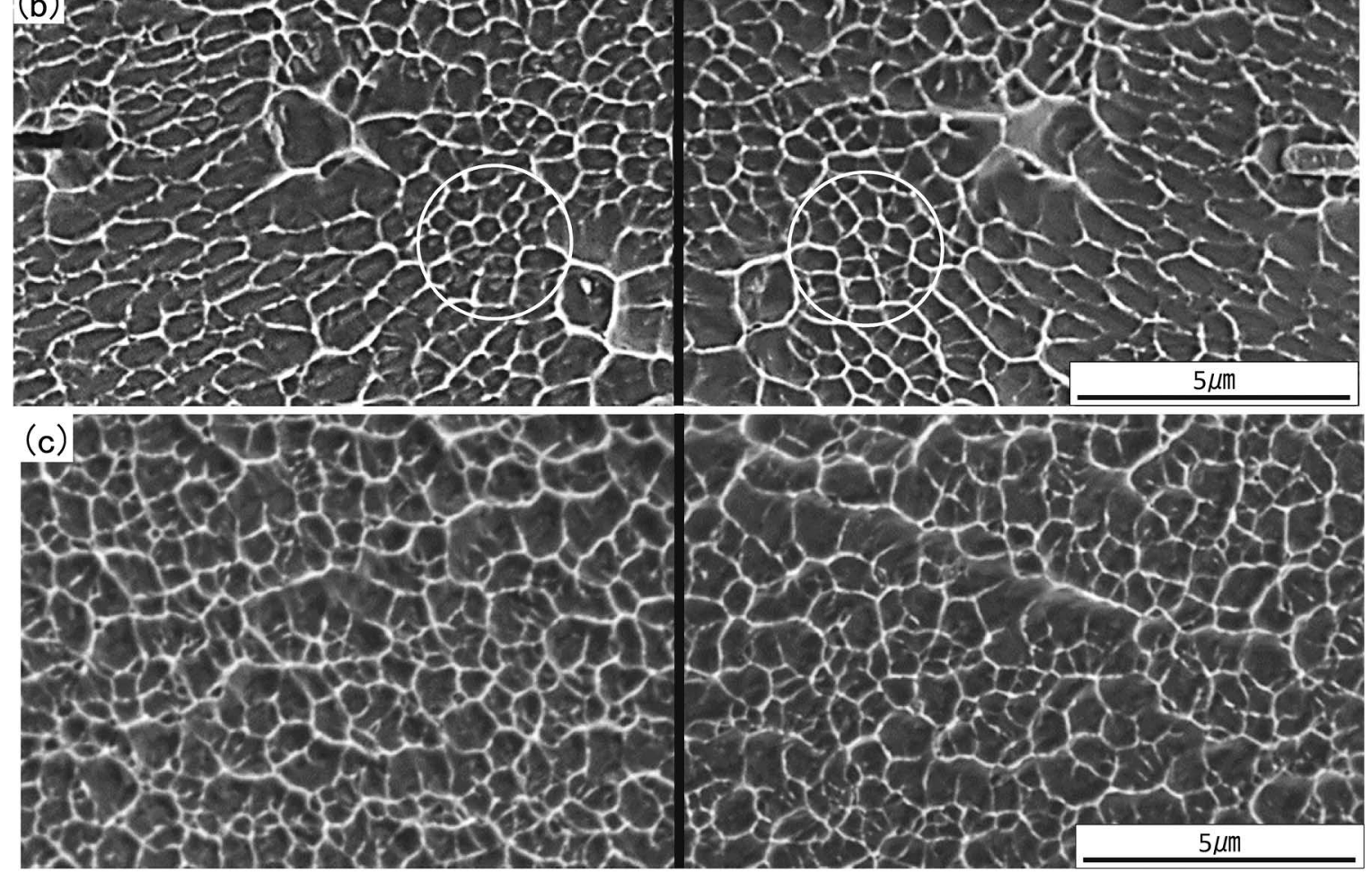

\section{s)}



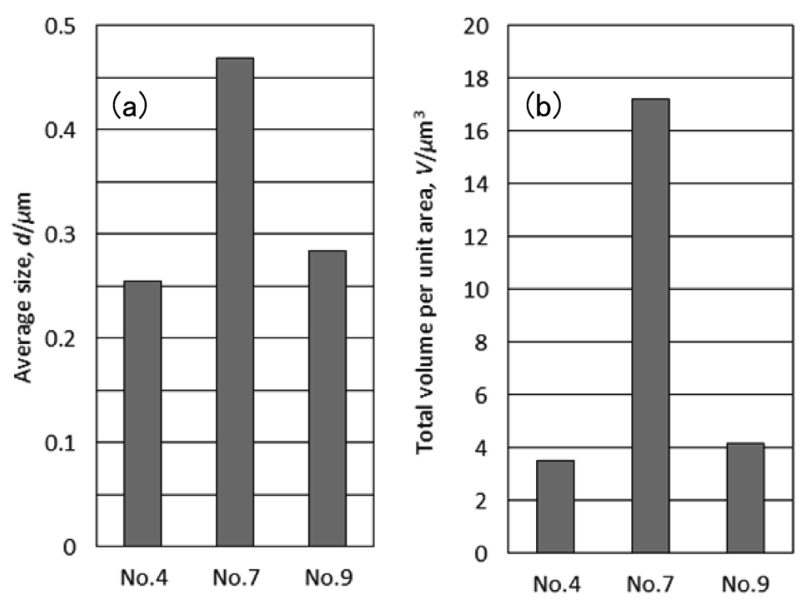

Fig. 8 Average size and the total volume of grain boundary precipitates observed in area of $560 \mu \mathrm{m}^{2}$.
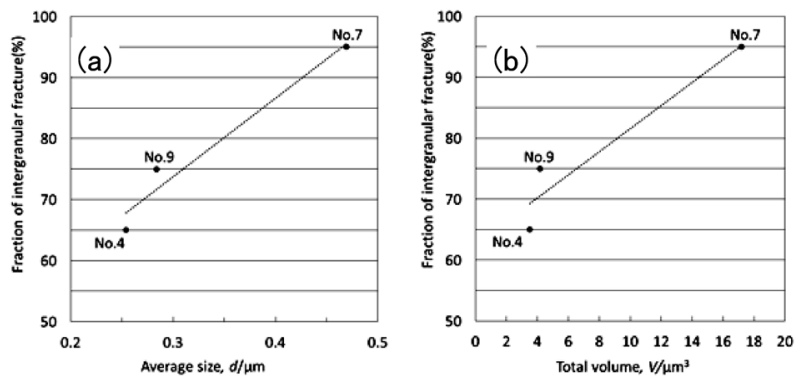

Fig. 9 Fraction of the intergranular fracture plotted against $d$ and $V$.

個々の析出物の体積を求めずに，ディンプル数に平均析出物 体積 $\left((4 / 3) \pi(d / 2)^{3}\right)$ を乗じることにより行った。No.7では $d も V も ，$ No. 4, No.9より大きいことが明らかである。 Fig. 6 で求めた粒界破面率を $d$ および $V$ に対してプロットし，Fig. 9 を得た。この図に示されるように粒界析出物寸法および粒界 析出量が増加するほど粒界割れの割合も多くなる傾向がわか る。

Fig. 10 に粒界近傍部の TEM 観察結果を示す。この像から 測定されたPFZ幅は，No. 4: $0.07 \mu \mathrm{m}, \quad$ No. 7: 0.12 $\mu \mathrm{m}$, No. 9: $0.08 \mu \mathrm{m}$ であり, 最も広いNo. 7でも最も狭いNo. 4のたかだか 1.7 倍である。Fig. 8(b) の粒界析出物の総体積（粒界析出量） では, No. 7 はNo. 4 やNo.9の4倍以上大きかった。PFZは, 主に溶質枯渇域に対応し, 溶質枯渇域の幅は粒界析出量に比 例するので ${ }^{24)}$, Fig. 8(b) からは, No.7のPFZ幅はNo. 4 やNo. 9のおよそ4倍と予測される。この予測結果は, TEM観察結果 と比べると大小関係は一致しているが, 定量的には異なる結 果となっている。これは, 本合金の粒内析出物が針状である ため，核生成した場所から粒界に向かって成長する場合もあ り，TEMではPFZを明確に測定しにくいためと考えられる。

一方, TEM観察結果から測定された粒界析出物寸法は, No. 4: $0.041 \mu \mathrm{m}$, No. 7: $0.044 \mu \mathrm{m}$, No. 9: $0.053 \mu \mathrm{m}$ であった。 これらの值は, Fig. 8(a) の破面上で測定した寸法の 1/5 以下 である。これは，TEMでは，薄膜を観察しているため数多 くの析出物について測定できないことや, 薄膜の厚さより大 きい析出物は寸法を過小評価する可能性が高いこと, 大きい 析出物が薄膜作製過程で脱落することなどの理由によると推 察される。したがって SEMによる破面観察（Fig. 8(a)）で

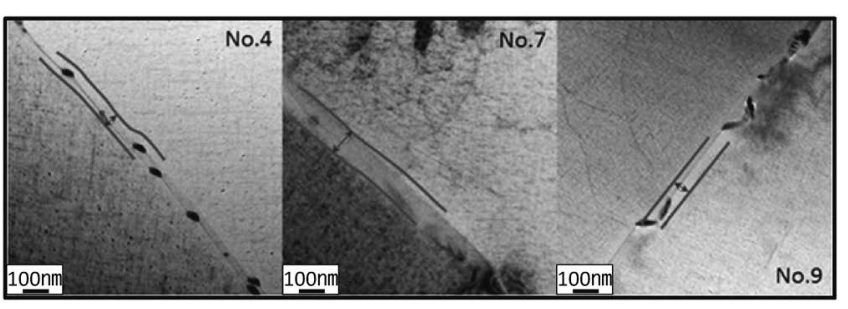

Fig. 10 TEM micrographs of a grain boundary area. Ends of precipitate free zone (PFZ) are indicated by lines or curves, and PFZ width is indicated by arrows.

得られた平均析出物寸法のほうが信頼性が高いと考えられ る。

以上のように, TEM観察では顕著に見えないが, No. 7 は No. 4 やNo. 9 に比べて粒界析出物寸法が大きく, PFZ幅が広 いという特徵があることが明らかになった。 $\mathrm{Al}-\mathrm{Zn}-\mathrm{Mg}, \mathrm{Al}-$ $\mathrm{Cu}, \mathrm{Al}$ - $\mathrm{Li}$ 合金の粒界近傍組織と破壊形態との関係を調査した Kuramotoらの報告 ${ }^{9)}$ によれば, 粒界析出物寸法が大きく PFZ 幅が広い組織の場合には，ディンプルを伴う粒界割れが起こり やすく低延性になるとされ, 本研究結果と一致する。さらに彼 らは, 粒界析出物が微細でPFZ幅が狭い場合に, 粒内のすべ りが粒界に堆積した場所で粒界拡散により粒界転位に組み込 まれる時間が十分にある場合には粒内延性破壊を示し，それ がない場合（極低温または高速変形）には，レッジ形成型の粒 界割れを示すと報告している9 。合金系は異なるが， $\mathrm{Al}-\mathrm{Mg}-$ $\mathrm{Si}$ 系に関する本研究結果でも, 粒界析出物寸法が小さく PFZが 狭いNo. 4 やNo. 9 で粒界破面率が低くなったこと（Fig. 9）は， 彼らの考えが合金系を問わず成立することを支持している。

上記に関係し，他の観察領域では Fig. 11 に示すように, No. 4 でレッジ形成型に近い（ディンプルも共存）粒界破壊が一 部で観察された。これは, No. 4では, 粒界析出物寸法が小 さくPFZ幅が狭かったことに関係していると思われた。No.7 やNo. 9ではこのようなレッジ形成型に近い破面は観察されな かったが, No.7では粒界析出物寸法が大きくPFZ幅が広かっ たためレッジ形成型ではなくディンプル形成型になったとし てよい。No.9ではNo. 4 と同程度に粒界析出物寸法が小さく PFZ幅が狭かったが, 粒界破面率が高いにもかかわらず高延 性となり, Fig. 11 に示されるレッジ形成型破面は見られなかっ た。これらのことは, No.4ではすべりが少数のすべり帯に集 中するのに対して, No.9では比較的変形の早期から分散した すべり帯ですべりが起こり, 粒界への応力集中がNo. 4 に比べ て少なかったと考えると, 矛盾なく理解できる。本研究の No. 4のような組成との比較ではないが, $\mathrm{Si}$ 過剩合金に $\mathrm{Cu}$ を添加 することにより，すべりが分散することが報告されている ${ }^{18)}$ 。

最後にしばしば議論される Si 過利合金における Si 相の析 出の有無について調べた。過利 Si 組成である No. 7, No. 9 の 粒界析出物の EDX解析の結果を Fig. 12 に示す。両試料共に $\mathrm{Si}$ のピークは認められるが, $\mathrm{Al}$ や $\mathrm{Mg}$ のピークよりも低いの で, $\mathrm{Si}$ 単相の粒界上析出物ではなく $\mathrm{Mg}_{2} \mathrm{Si}$ 相だと判断され る。ほかにも各試料について10個の粒界上析出物を分析し たが, $\mathrm{Si}$ のピークが $\mathrm{Al}$ や $\mathrm{Mg}$ より高くなる析出物は確認でき なかった。したがって $175^{\circ} \mathrm{C}$ 程度のピーク時効では過剩 $\mathrm{Si}$ 合 金でも $\mathrm{Si}$ 相は析出しないと判断された。 


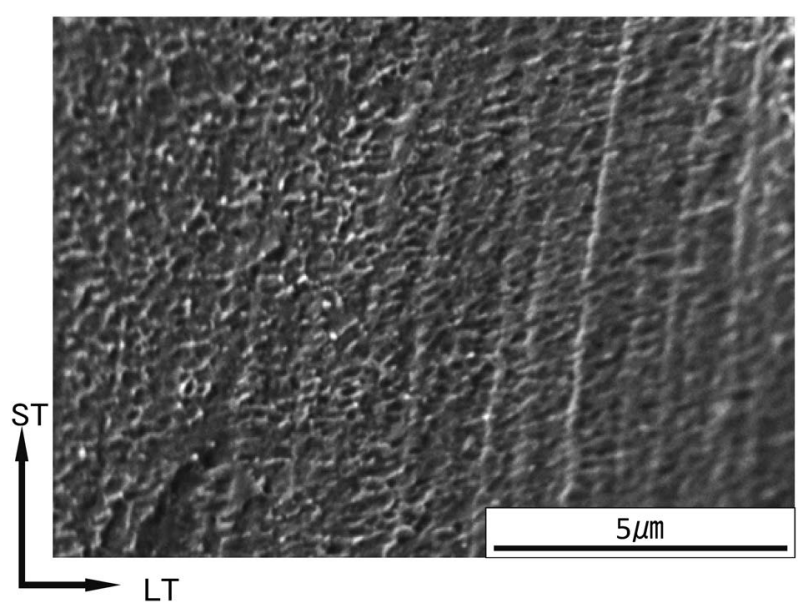

Fig. 11 Intergranular fracture surface of No. 4, showing a ledge-type intergranular fracture surface.

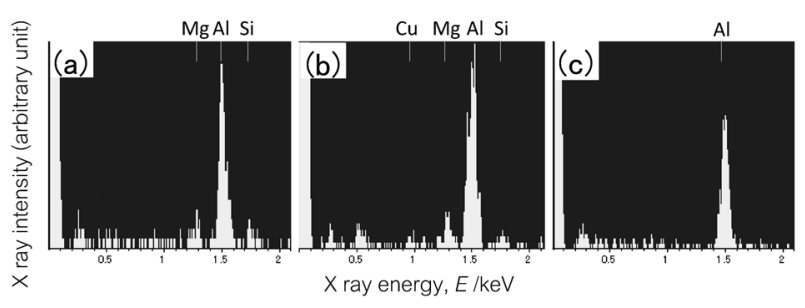

Fig. 12 EDX spectra taken from the precipitates and matrix shown in Fig. 7, (a) precipitate in No. 7, (b) precipitate in No. 9, (c) matrix in No. 7. Peak positions of $\mathrm{Cu}, \mathrm{Mg}, \mathrm{Al}$ and $\mathrm{Si}$ are indicated in the figure.

\section{4. 結言}

本研究では主要元素のうち, $\mathrm{Mg}$ 量が同一で $\mathrm{Cu}, \mathrm{Si}$ 量の異 なる $\mathrm{Al}-\mathrm{Mg}-\mathrm{Si}$ 系合金を用いて, 実験室大気環境で引張試験 を行った後, 主にSEMによる破面観察を行い, 粒界破壊に 及ぼす粒界近傍組織の影響を検討した。得られた結果を以下 に示す。

（1）同じ $\mathrm{Mg}$ 量 $\left(\mathrm{Mg}_{2} \mathrm{Si}\right.$ 量）ならば, $\mathrm{Si}$ 過剰合金のほうが, また $\mathrm{Cu}$ を添加したほうが高強度（高硬度）であることが確 認された。一方破断伸びは, Si 過剩で Cu無添加のNo.7が最 も小さく, バランス組成の No. 4, Si 過剩で $\mathrm{Cu}$ 添加の No. 9 の順に大きくなった。

（2）どの試料も粒界割れが支配的であったが，バランス 組成のNo. 4 が最も粒界破面率が低く, $\mathrm{Si}$ 過剰 $\mathrm{Cu}$ 無添加の No. 7が最も粒界破面の率が高くなること, $\mathrm{Si}$ 過剩で $\mathrm{Cu}$ 添加 のNo.9で粒界割れが抑制されることが確認された。

（3）いずれの試料に拈いても, 粒界破面のほとんどが ディンプル形成型の粒界破面であり，ほぼすべてのディンプ ルの底に粒界析出物を確認することができた。

(4) No. 4, No.9では, 対応する各面ともに場所によら ずほぼ同数の粒界析出物が分布していたが, No.7では片側 の面により多くの粒界析出物が存在する領域が見られた。

（5）No. 7 は No. 4 やNo. 9 に比べて粒界析出物寸法および 粒界析出量が著しく大きかった。粒界析出量から, PFZ幅が 著しく広いと判断された。粒界析出物寸法が大きくPFZ幅が
広いほど，粒界破面率が高くなる傾向が確認された。

（6）No.4でレッジ形成型に近い粒界破壊が一部で観察さ れた。これは, 粒界析出物寸法が小さく PFZ幅が狭いことに 関係していると思われた。

（7）過剩 Si 組成であるNo. 7, No.9の粒界析出物の EDX 解析の結果, ピーク時効程度の条件で粒界上に $\mathrm{Si}$ 相は析出 しないと判断された。

以上より， $\mathrm{Al}-\mathrm{Mg}-\mathrm{Si}$ 系合金で $\mathrm{Si}$ 過剰にするとバランス合金 と比較して粒界析出量が増大し PFZ幅が広くなることで粒界 割れが起きやすくなり, Cuを添加すると粒界析出物を微細に しPFZ幅が狭くなるので粒界割れが少なくなると結論された。 謝 辞

本研究の一部は, 公益財団法人軽金属奨学会の教育研究資 金およびJSPS 科研費JP17K06854により行われました。また 試料作製およびTEM観察を日本軽金属株式会社にご協力い ただきました。関係各位に感謝致します。

\section{参 考 文 献}

1) 伊藤吾朗：材料と環境，65（2016），432-437.

2) NEDO:「水素利用技術研究開発事業/燃料電池自動車及び水素 供給インフラの国内規制適正化, 国際基準調和・国際標準化に 関する研究開発/自動車用圧縮水素容器の基準整備・国際基準 調和に関する研究開発」, 平成 25 年度 平成 29 年度のうち平成 25 年度分中間年報, $(2014), 1$.

3) NEDO:「水素利用技術研究開発事業/燃料電池自動車及び水素 供給インフラの国内規制適正化, 国際基準調和・国際標準化に 関する研究開発/自動車用圧縮水素容器の基準整備・国際基準 調和に関する研究開発」, 平成 25 年度 平成 29 年度のうち平成 27 年度分中間年報, (2016), 16 .

4) NEDO :「水素利用技術研究開発事業/燃料電池自動車及び水素 供給インフラの国内規制適正化, 国際基準調和・国際標準化に 関する研究開発 /自動車用圧縮水素容器の基準整備・国際基準 調和に関する研究開発」, 平成 25 年度 平成 29 年度のうち平成 28 年度分中間年報, $(2017), 11-15$.

5）松田健二, 池野 進：軽金属，53（2003），457-462.

6) J. Aucote and D. W. Evans: Met. Sci., 12 (1978), 57-63.

7) 上谷保裕, 石動正和, 松田健二, 多々静夫, 池野 進 : 軽金属, 42 (1992), 578-584.

8）菅野幹宏, 鈴木 寿, 白石泰久：軽金属, 28 (1978), 553-557.

9) S. Kuramoto, G. Itoh and M. Kanno: Metall. Mater. Trans. A, 27A (1996), 3081-3088.

10) 中川惠友, 金谷輝人, 細川智生, 谷本 雅 : 軽金属, 50 (2000) 650-654.

11) 中川惠友, 金谷輝人, 伊藤吾朗, 細川智生, 谷本 雅：軽金属, 53 (2003)， 104-109.

12）中川惠友, 金谷輝人, 長岡紀幸, 柇原 精, 伊藤吾朗 : 日本金 属学会誌, 70 (2006), 897-904.

13) K. G. Kent: J. Inst. Met., 97 (1969), 127-128.

14）村上陽太郎：軽金属, 31 (1981), 748-757.

15）伊藤吾朗, 江藤武比古, 宮木美光, 菅野幹宏: 軽金属, 38 (1988), 818-839.

16）大西忠一, 茨木良昭：軽金属, 40（1990），82-87.

17）川畑 武：軽金属, 33 (1983)，38-54.

18）松田健二, 名徳康晴, 木戸耕介, 上谷保裕, 池野 進：軽金属, 53 (2003), 2-7.

19）渡辺忠雄：日本金属学会会報, 22（1983），95-102.

20) G. A. Chadwick: Metallography of Phase Transformations, Butterworths, (1972), 195-200.

21）大堀紘一: 軽金属, 38 (1988), 748-763.

22）馬場義雄：軽金属, 30 (1990), 520-532.

23）菅野幹宏, 斎藤 洋, 鈴木 寿: 軽金属, 37 (1987), 375-380. 24）畑 栄一, 馬場義雄: 日本金属学会会報, 18（1979）, 478-482. 